\title{
Infecção por hemoplasmas em felinos domésticos na região de Porto Alegre, RS, Brasil*
}

\author{
ANDREA PIRES DOS SANTOS
}

\author{
Félix Hilario Díaz González (Orientador - UFRGS)
}

Banca: Alexander Welker Biondo (UFPR), Luis Sangioni (UFSM), Sérgio Ceroni da Silva (UFRGS)

O hemoplasma refere-se ao grupo de micoplasmas que parasitam os eritrócitos do hospedeiro e podem causar anemia. $\mathrm{O}$ uso das técnicas baseadas na reação em cadeia da polimerase (PCR) tem sido utilizadas para a melhor compreensão da doença. No Brasil, os hemoplasmas Mycoplasma. haemofelis e 'Candidatus Mycoplasma. haemonminutum já foram identificados, porém dados de prevalência e fatores de risco não foram avaliados até o momento. A espécie 'Candidatus Mycoplasma turicensis' já foi descrita em diferentes países, mas a técnica de diagnóstico utilizando PCR em tempo real limita seu estudo no Brasil devido ao custo e a necessidade de pessoal especializado. O presente trabalho desenvolveu uma técnica por PCR convencional para a detecção da espécie 'Candidatus M. turicensis' e descreve pela primeira vez sua presença infectando gatos domésticos no Brasil e a prevalência, fatores de risco e achados hematológicos da infecção por hemoplasmas foi avaliada. No total de 371 gatos, 79 (21.3\%) foram positivos para pelo menos uma espécie de hemoplasma. A infecção por 'Candidatus M. haemominutum' foi detectada em 50 (13,48\%) dos animais, 'Candidatus M. turicensis' e M. haemofelis foram detectados em 10/371 (2.69\%) e 8/371 (2.16\%) dos animais, respectivamente. Coinfecção com M. haemofelis- 'CandidatusM. haemominutum' foi detectada em 4/371 (1.08\%), 'Candidatus M. haemominutum'- 'Candidatus M. turicensis' em 5/371 $(1.35 \%)$ e infecção tripla em 2/371 (0.54\%). Gatos machos, jovens e com acesso à rua são mais susceptíveis a infecção por hemoplasmas. Anemia é associada à infecção por M. haemofelis e 'Candidatus M. haemominutum'. O presente trabalho também descreve a infecção por micoplasma hemotrófico, similar ao M. haemofelis em um paciente humano HIV positivo e alerta para seu potencial zoonótico. Em conclusão, espécies de hemoplasmas são comuns e importantes agentes de infecções em gatos domésticos no sul do Brasil. Estudos futuros devem ser conduzidos para melhor entender seu impacto em animais de companhia e determinar o seu papel como agentes zoonóticos, particularmente em pessoas imunocomprometidas.

Descritores: Micoplasma, hemoplasma, anemia infecciosa felina, zoonose, HIV, PCR.

\footnotetext{
*Tese de Doutorado n. 99 (Especialidade: Patobiologia).162f Programa de Pós-Graduação em Ciências Veterinárias [www.ufrgs.br/ppgcv], Faculdade de Veterinária, Universidade Federal do Rio Grande do Sul (UFRGS). Porto Alegre/RS. CORRESPONDÊNCIA: A.P. Santos [santos1@purdue.edu]
} 


\title{
Haemoplasma infection in domestic cats from Porto Alegre, RS, Brazil**
}

\author{
ANDREA PIRES DOS SANTOS
}

Félix Hilario Díaz González (Adviser - UFRGS)

Committee: Alexander Welker Biondo (UFPR), Luis Sangioni (UFSM), Sérgio Ceroni da Silva (UFRGS)

The term haemoplasma refers to the mycoplasmas that parasitize the red blood cells of the host and can cause anemia. Molecular approaches based on the polymerase chain reaction (PCR) have been used to better understand the disease. In Brazil, The species Mycoplasma haemofelis and 'Candidatus Mycoplasma haemominutum' were identified, whereas prevalence and risk factor were not evaluated to date. The specie 'Candidatus Mycoplasma turicensis' was described in many countries, however the use of real time-PCR for the diagnostic of the infection had limited its use in Brazil and other countries since it is expensive and requires specialized technicians. The current study developed a conventional PCR assay to the diagnosis of 'Candidatus M. turicensis' and report for the first time the infection in domestic cats in Brazil. We also evaluated the prevalence, risk factors and hematological findings for the hemoplasma infections. In a total of 371 cat samples, $79(21.3 \%)$ were PCR-positive for at least one species of haemoplasma. 'Candidatus M. haemominutum' infection was found in 50 out of $371(13.48 \%)$ positive cats, 'Candidatus M. turicensis' and M. haemofelis DNA were found in 10/371 (2.69\%) and 8/371 (2.16\%) of the cats respectively. Coinfection with M. haemofelis- 'Candidatus M. haemominutum' was found in 4/371 (1.08\%), 'Candidatus M. haemominutum'- 'Candidatus M. turicensis' in 5/371 (1.35\%) and infection with all 3 haemoplasmas in 2/371 $(0.54 \%)$. Male cats, younger age and outdoor access were risk factors for haemoplasma infection. Anemia was associated with M. haemofelis and 'Candidatus M. haemominutum' infection. The present study also reports a case of a Mycoplasma haemofelislike organism infection in a HIV positive patient and warns the zoonotic potential of the haemoplasmas. In conclusion, the haemoplasmas are common infectious agent in domestic cats in southern Brazil. Further studies are needed to better understand their impact on companion animals, as well as their role as zoonotic agents, particularly in immunocompromised people.

Key words: Mycoplasma, haemoplasma, feline infectious anemia, zoonosis, HIV, PCR.

Presented: 12 September 2008

** Doctoral Dissertation \# 99 (Field: Patobiology)162p. Graduate Program in Vetrerinary Sciences [www.ufrgs.br/ppgcv], Faculdade de Veterinária, Universidade Federal do Rio Grande do Sul (UFRGS). Porto Alegre/Brazil. CORRESPONDENCE: A.P. Santos [santos1@purdue.edu]. 